\title{
Acute Urticaria Related to Cow’s Milk Allergy in Newborn Period
}

\section{Yenidoğan Döneminde Akut Ürtiker İle Prezente Olan İnek Sütü Proteini Alerjisi}

\section{(D) Yasemin Eroğlu1, (D) Hikmet Tekin Nacaroğlu², (D) Abdulrahman Özel1, (D) Özgül Yiğit1, (D) Fatih Mete}

${ }^{1}$ Bağcılar Training and Research Hospital, Clinic of Pediatrics, İstanbul, Turkey

2İstanbul Medipol University Faculty of Medicine, Department of Pediatric Allergy and Immunology, İstanbul, Turkey

\section{Abstract}

Urticaria is a common disease in children. But there are few case reports in neonatal period. Urticaria has many causes, unfortunately it cannot be figured out in some of the cases. Drug and food allergies, infections are common reasons that have been commonly shown. IgE-mediated food allergy should be considered in patients with acute urticaria and/or angioedema after food intake. Here we present a case of acute urticaria due to cow's milk protein allergy in the newborn period. A 21-day-old male patient was admitted to our emergency department with the complaint of widespread rash on the body which started one day earlier. Medical history has revealed that he did not have a different drug intake before the onset of complaints, had no previous rashes, upper respiratory tract infection or other infective-inflammatory disease since birth. His parents did not admit to another hospital. We obtained blood tests for food allergy. Total IgE: $38 \mathrm{IU} / \mathrm{L}$ and cow's milk protein-specific IgE (f2): $2.26 \mathrm{kU} / \mathrm{L}$ were found to be suspicious for food allergy. According to these results, the formula which the baby was treated before has been stopped and extensively hydrolyzed formula has been started. After 12 hours, urticaria had started to fade. While going on our treatment, on $5^{\text {th }}$ day the urticaria lesions totally disappeared. Although urticaria is a common disease, it is rarely reported in patients under six months. We want to emphasize that food allergies may be considered in cases presenting with urticaria in neonatal period.

Keywords: Cow's milk allergy, urticaria, newborn

\section{Öz}

Ürtiker, küçük çocuklarda çok sık görülen medikal bir problemdir. Yenidoğan döneminde ise az sayıda olgu bildirimi vardır. Ürtikerin birçok olguda nedeni bulunamasa da oldukça fazla nedeni vardır. Daha çok gıda alerjisi, ilaç etkisi veya enfeksiyonlara bağlı meydana geldiği gösterilmiştir. Besin alımı sonrası akut ürtiker ve/veya anjioödem görülen hastalarda IgE aracılı besin alerjisinin olabileceği mutlaka akla getirilmelidir. Bu yazıda ise yenidoğan döneminde inek sütü proteini alerjisine bağlı gelişen akut ürtiker olgusı sunulmuştur. Yirmi bir günlük erkek hasta acil servisimize 1 gün önce başlayan vücuttaki yaygın döküntü şikayeti ile başvurdu. Hastanın öyküsünde şikayetleri başlamadan önce farklı bir ilaç alımı olmadığı, daha önce döküntülerinin olmadığı, doğumundan bu yana üst solunum yolu enfeksiyonu veya başka bir enfektif-enflamatuvar hastalık geçirmediği ve başka bir tıbbi kuruma başvurmadıkları öğrenildi. Hastanın besin alerjisi şüphesi açısından alınan tetkiklerinde Total IgE: $38 \mathrm{IU} / \mathrm{L}$, süt spesifik IgE (f2): 2,26 kU/L olarak saptandı. Bu sonuçlara göre olgunun almış olduğu formüla mama kesilerek ileri derece hidrolize formüla başlanıldı. İzlemde olgunun 12 saat sonra vücuttaki döküntülü lezyonlar solmaya başladı ve tedavisinin 5. gününde tüm lezyonları düzeldi. Ürtiker, sık görülen bir hastalık olsa da 6 aydan küçük olgularda nadir olarak bildirilmektedir. Yenidoğan döneminde ürtiker tablosu ile başvuran olgularda besin alerjisi olabileceğinin akılda tutulması gerektiğini vurgulamak için olgumuz sunulmuştur.

Anahtar kelimeler: İnek sütü protein alerjisi, ürtiker, yenidoğan

Address for Correspondence: Hikmet Tekin Nacaroğlu, İstanbul Medipol University Faculty of Medicine, Department of Pediatric Allergy and Immunology, İstanbul, Turkey

E-mail: tekin212@gmail.com ORCID ID: orcid.org/0000-0003-1333-2648 Received: 25.10.2019 Accepted: 15.11.2019

Cite this article as: Eroğlu Y, Tekin H, Özel A, Yiğit Ö, Mete F. Acute Urticaria Related to Cow's Milk Allergy in Newborn Period. Bagcilar Med Bull 2019;4(4):110-113

@Copyright 2019 by the Health Sciences University, Bagcilar Training and Research Hospital Bagcilar Medical Bulletin published by Galenos Publishing House. 


\section{Introduction}

Urticaria is a very common medical problem in young children. Although the exact prevalence is unknown, it is estimated to be $20 \%$ (1). Characteristic finding in urticaria is well-circumscribed, surface-raised erythematous plaques. They are transient lesions with marked margins or tendency to converge and fade by pressing. Each swelling doesn't exist more than 24 hours and the lesions are often itchy. Mast cells in the superficial dermis play a key role in the pathogenesis of urticarial $(1,2)$. Clinical manifestations lasting less than 6 weeks are called "acute urticaria" and the ones which exist 6 weeks or more are called chronic urticarial $(3,4)$. Although the cause of urticaria is not found in many cases, there are many reasons. It should be kept in mind that patients with acute urticaria and/or angioedema after food intake may have IgE-mediated food allergy $(1,2)$. IgE-mediated food allergy is observed in approximately $10 \%$ of pediatric patients presenting with acute urticaria, whereas food is rarely (2\%) causative in chronic urticaria patients (1). Eggs, milk, soy, peanuts and wheat are the most commonly accused foods in young children, while fish, shellfish and nuts are blamed in older children (3).

Although urticaria is a common disease, it is rare to occur at a age of less than 6 months. There are few reports in the neonatal period (5). It is mostly linked to food allergy, drug action or infections. Since urticaria is rare at age less than 6 months and only a few treatments have been tried for its efficacy and safety, little information is available about treatment in the literature $(6,7,8,9)$. In this report, we present a case of acute urticaria due to cow's milk protein allergy in the newborn period.

\section{Case Report}

A 21-day-old male patient was admitted to our emergency department with the complaint of widespread rash on the body that started one day earlier. The patient's history revealed that he did not have a different drug intake before the onset of complaints, had no previous rashes, did not experience upper respiratory tract infection or other infective-inflammatory disease since birth, and had not consulted another medical institution. It was learned from the patient's history and family history that she was the first child of unrelated parents, that he was born vaginally at the $40^{\text {th }}$ gestational week following a problem-free pregnancy and that the mother started breastfeeding from the first hour. It was learned that intermittent formula was initiated because of insufficient breast milk in the first week of the patient's nutrition and that he fed on only formula due to the discontinuation of breast milk during follow-up. In the skin examination; there were widespread plaques that held the extremities and trunk, tend to merge in places, puffy from the skin, migratory, fading with pressure, and occasionally left a purplish discoloration (Figure 1). No mucosal involvement was observed. Laboratory examination of the patient revealed white cells of $16.350 \mathrm{~mm}^{3}$, hgb: $17.3 \mathrm{gr} /$ dL, plt: $288.000 \mathrm{~mm}^{3}$, eosinophil count: $500 \mathrm{~mm}^{3}$ and a normal total biochemistry except a rise in Crp which was $3.21 \mathrm{mg} / \mathrm{L}$ (N: 0-5). Bleeding profile was normal. Serological examinations for congenital infections were negative. Complete urinalysis was normal. No fecal occult blood was detected. Total IgE: 38 IU/L, milk specific IgE (f2) levels were detected in the patient's food allergy suspicion; 2.26 $\mathrm{kU} / \mathrm{L}$. According to these results, the formula taken was stopped and the hydrolyzed form was started. During the follow-up, the rash lesions began to fade within 12 hours and all lesions disappeared on the $5^{\text {th }}$ day of treatment. The patient was advised to continue with a highly hydrolyzed form and was discharged with an appointment for oral loading test after a 2-week elimination diet. But oral food loading test could not be performed because the family did not consent. The milk specific IgE (f2) level at the age of 4 months was found to be $5.8 \mathrm{kU} / \mathrm{L}$, andthe diet elimination was continued.
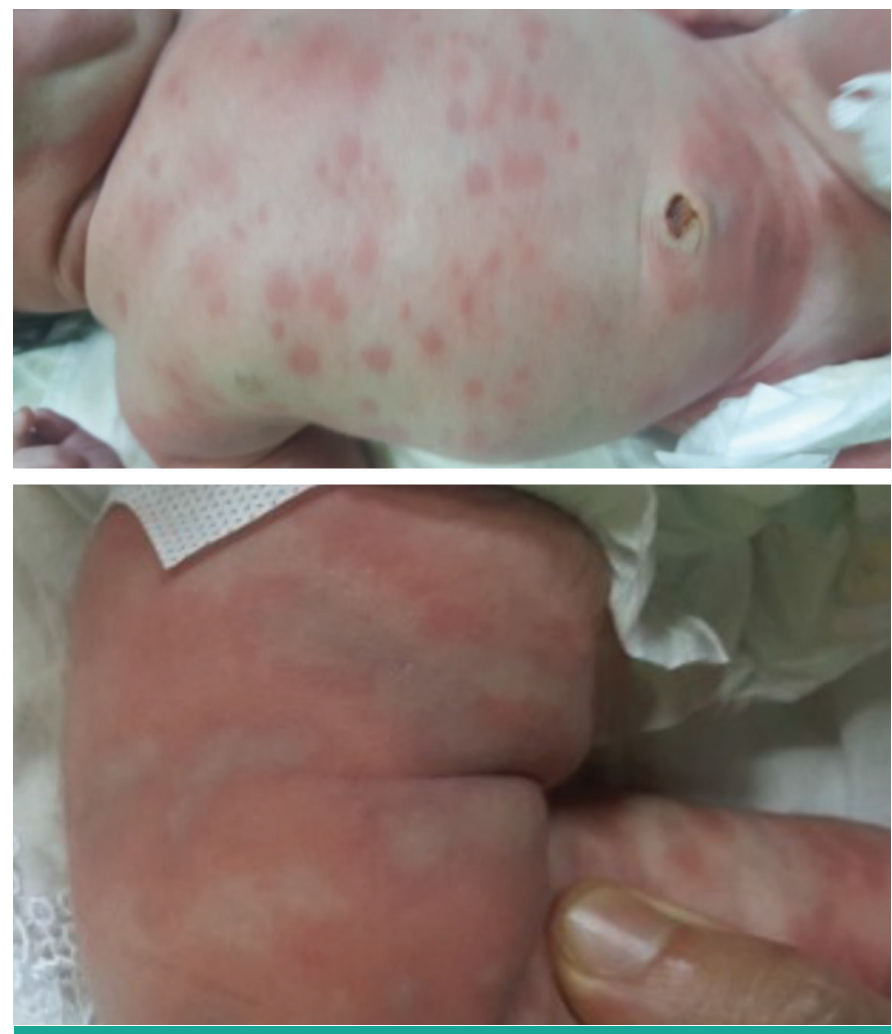

Figure 1. Skin examination 


\section{Discussion}

IgE-mediated food allergy should be considered in patients with acute urticaria and/or angioedema after food intake. Our case was an acute urticaria due to cow's milk protein allergy in the newborn period.

Classical findings of urticaria consists of papules and plaques of pink, red, edematous, different sizes of geographic or annular character. It can hold any place on the skin. If it is generalized, the lesions may merge. But the lesions are temporary, they can be displaced within hours. It is typically less than 24 hours in the same location. In the literature, all types of urticaria described in patients younger than 6 months showed an acute course $(6,7)$. There were no reports of chronic urticaria at this age. In our case, the lesions in the body were evaluated as acute urticaria due to the non-sequelae healing within 5 days after starting with the highly hydrolyzed form.

The most common causes of urticaria in children are infections, food allergy, medications, insect bites. However, the majority of patients younger than 6 months present with food allergy and infections as the cause $(6,7,8,9)$. Legrain et al. (7) accused cow's milk responsible for $75 \%$ as the causative agent of acute urticaria in patients younger than 6 months. Hon and So (10) reported annular target-like rashes in the literature in a 24-day-old male patient. During the follow-up examinations, no infectious etiology (blood, cerebrospinal cultures: negative) was detected in laboratory examinations, but as evidence of atopy; reported high levels of eosinophilia (eosinophil percentage: 13\%) and IgE (216 kIU/L). The authors suggested that atopic newborns may be prone to acute urticaria and eczematous rashes and should be monitored in this respect. Huston et al. (11) found that the content of the parenteral nutritional, namely; amino acid solution, lipid solution, multivitamins and magnesium sulfate may also be associated with hypersensitivity reactions in the study performed in the neonatal intensive care unit receiving parenteral nutritional therapy.

Demirdöven et al. (12) reported a case of anaphylaxis after feeding with cow's milk-based formula in a newborn on postnatal $16^{\text {th }}$ day. The patient was treated with intravenous adrenaline, antihistaminic and dexamethasone, and nebulized salbutamol (albuterol). The patient was fed only breast milk during the follow-up and the mother started a diet that did not contain cow's milk protein. Again, in the literature, Lifschitz et al. (13) reported that anaphylaxis was observed following the use of cow milk protein-based formula in an 8-day-old newborn. Tarım et al. (14) reported that anaphylaxis developed with partial-hydrolyzed formula in a 7-week-old baby with a familial history of atopy who was admitted to the hospital with cardiac arrest and died 21 hours later. In our case, cow's milk protein allergy was considered only because he had been taking formula due to the discontinuation of breast milk. Later cow's milk protein allergy was confirmed by the diagnostic tests as well.

It is important to take a detailed history in the diagnosis of cow's milk allergy. The age of patient, onset of symptoms, the frequency of occurrence, the time between food intake and the reaction, triggering factors ant the amount and type of cow's milk that triggers symptoms should be questioned $(15,16)$. Detailed history and laboratory tests are essential for the diagnosis. Milk specific IgE, skin prick tests, skin patch tests are helpful; however oral food loading test is the gold standard in diagnosis $(17,18)$. Cow milk specific IgE measurement is a high sensitivity and low specificity test with quantitative method (CAP or Immulite system) in serum which is frequently used in diagnosis. This test is not affected by the drugs used by the patient; there is no risk of reaction during the test (19). Milk specific IgE levels higher than $0.35 \mathrm{kU} / \mathrm{L}$ indicate sensitization; however, it is not enough for the diagnosis. Positive results must be correlated with the clinic. For milk-specific IgE, $\geq 5 \mathrm{kU} / \mathrm{L}$ in children younger than 2 years and $\geq 15 \mathrm{kU} / \mathrm{L}$ in children older than 2 years have been reported to be diagnostic with $95 \%$ positive predictive value (18). In our case, the elimination diet was continued as the milk-specific IgE level at the age of 4 months was above the positive predictive value of $5.8 \mathrm{kU} / \mathrm{L}$.

In the classical treatment of cow's milk allergy, it is necessary to start a cow milk elimination diet. Elimination diet is a very difficult process, affecting the quality of life of the patient and the family and preventing accidental intake is difficult. Elimination diet should be given to each patient with a list of nutrients that should not be consumed, information about alternative foods, and with a whole education for compliance of patients and their parents, prevention of accidental ingestions, and immediate treatment of acute reactions. The follow-up of patient's growth and development should be planned in the treatment as well. If there is a symptom while feeding with breast milk, it is necessary to remove milk and dairy products from the mother's diet and start with $1000 \mathrm{mg} /$ day calcium supplementation appropriately. Highly hydrolyzed or amino acid-based formulas are used in children under two years of age who have insufficient breastfeeding or who cannot eat at all. In the absence of severe symptoms, 
the first choice is highly hydrolyzed formulas. Amino acidbased formulas are used as the first choice if there is no response to treatment with highly hydrolyzed formulas, or in high-risk situations (such as anaphylaxis), or if growth and developmental retardation accompany, or in the presence of eosinophilic esophagitis or other severe symptoms (20). Due to the absence of breast milk, our case was started with highly hydrolyzed formula. In our patient who had clinical improvement with treatment, outpatient follow-up is continued in terms of monitoring growth and tolerance development.

\section{Conclusion}

It is important to keep in mind that the rashes observed in the neonatal period may be worrisome and sometimes may be associated with sepsis, which is life-threatening. It should be kept in mind that atopic neonates may present with acute urticaria and eczematous rashes as well.

\section{Ethics}

Informed Consent: Informed consent was obtained from the patients.

Peer-review: Externally peer-review.

\section{Authorship Contributions}

Concept: Y.E., H.T.N., Design: Y.E., H.T.N., Data Collection or Processing: Y.E., H.T.N., A.Ö., Analysis or Interpretation: F.M., Literature Search: Ö.Y., F.M., Writing: Y.E., H.T.N., A.Ö.

Conflict of Interest: No conflict of interest was declared by the authors.

Financial Disclosure: The authors declared that this study received no financial support.

\section{References}

1. Zuberbier T, Asero R, Bindslev-Jensen C, Walter Canonica G, Church MK, Giménez- Arnau A, et al. EAACI/GA (2) LEN/EDF/ WAO guideline: definition, classification and diagnosis of urticaria. Allergy 2009;64:1417-1426.

2. Mosidi T, Wong L, Jessop S. Acute urticaria in infancy: skin focus. Current Allergy \& Clinical Immunology 2008;21:184-186.

3. Sicherer SH, Leung DY. Advances in allergic skin disease, anaphylaxis, and hypersensitivity reactions to foods, drugs, and insects in 2010. J Allergy Clin Immunol 2011;127:326-335.
4. Schaefer P. Acute and Chronic Urticaria: Evaluation and Treatment. Am Fam Physician 2017;95:717-724.

5. Erdeve Ö, Erdeve ŞS, Sarıcı Ü. Neonatal Urticaria Due To Topical Mupirocin. Erciyes Med J 2011;33:149-152.

6. Mortureux P, Léauté-Labrèze C, Legrain-Lifermann V, Lamireau T, Sarlangue J, Taïeb. Acute urticaria in infancy and early childhood: a prospective study. Arch Dermatol 1998;134:319-323.

7. Legrain V, Taïeb A, Sage T, Maleville J. Urticaria in infants: a study of forty patients. Pediatr Dermatol 1990;7:101-107.

8. Ferdman RM, Shaham B, Church JA. Neonatal urticaria as a symptom of a multisystem inflammatory disease. J Allergy Clin Immunol 2000;106:986-987.

9. Carder KR. Hypersensitivity reactions in neonates and infants. Dermatol Ther 2005;18:160-175.

10. Hon KL, So KW. A target annular rash in an atopic neonate. Hong Kong Med J 2013;19:365.e1-2.

11. Huston RK, Baxter LM, Larrabee PB. Neonatal Parenteral Nutrition Hypersensitivity: A Case Report Implicating Bisulfite Sensitivity in a Newborn Infant. JPEN J Parenter Enteral Nutr 2009;33:691-693.

12. Demirdöven M, Keleș E, Gebeșçe A, Yazgan H, Kaya M, Tonbul A. Anaphylactic Shock Due to Cow's Milk Allergy in the Neonatal Period. Breastfeed Med 2015;10:341.

13. Lifschitz CH, Hawkins HK, Guerra C, Byrd N. Anaphylactic shock due to cow's milk protein hypersensitivity in a breastfed infant. J Pediatr Gastroenterol Nutr 1998;7:141-144.

14. Tarım O, Anderson WM, Lifshitz F. Fatal anaphylaxis in avery young infant possibly due to a partially hydrolyzed whey formula. Arch Pediatr Adolesc Med 1994;148:1224- 1229

15. Sicherer SH, Sampson HA Food allergy: epidemiologt, pathogenesis 2014;133:291- 307.

16. Sampson HA, van Wijk R, Bindslev-Jensen C, Sicherer S, Teuber SS, Burks AW, et al. Standardizing double blind, placebo-controlled oral food challenges: American Academy of Allergy, Asthma \& Immunology-European Academy of Allergy nad Clinical Immunology PRACTALL consensus report. J Allergy Clin Immunol 2012;130:1260-1274.

17. Wang J, Sampson HA. Food Allergy. J Clin Invest 2011;121:827-835.

18. Sampson HA. Utility of food-specific IgE concentrations in predicting symptomatic food allergy. J Allergy Clin Immunol 2001;107:891-896

19. Kulis M, Wright BL, Jones SM, Burks AW. Diagnosis, managment and investigatioanel therapies for food allergies. Gastroenterology 2015;148:1132-1142.

20. Fiocchi A, Brozek J, Schünemann H, Bahna SL, von Berg A, Beyer $\mathrm{K}$, et al. Allergy Organization (WAO) Diagnosis and Rationale for Action against Cow's Milk Allergy (DRACMA) Guidelines. Pediatr Allergy Immunol 2010;21:1-125. 